\title{
Admitting Deserving Medical Students from Rural and Disadvantaged: Patan Academy of Health Sciences' Approach
}

Shambhu Kumar Upadhyay, ${ }^{1}$ Shital Bhandary, ${ }^{1}$ Dil Bahadur Bhandari, ${ }^{1}$ Ram Krishna Dulal, ${ }^{1}$ Kedar Prasad Baral, ${ }^{1}$ Rajesh Nath Gongal, ${ }^{5}$ Paras Kumar Acharya, ${ }^{2}$ Shrijana Shrestha, ${ }^{3}$ Jay Narayan Shah, ${ }^{4}$ Arjun Karki ${ }^{5}$

${ }^{1}$ Department of Community Health Sciences, Patan Academy of Health Sciences, Lalitpur, Nepal, ${ }^{2}$ Department of Medicine, Patan Academy of Health Sciences, Lalitpur, Nepal, ${ }^{3}$ Department of Pediatrics, Patan Academy of Health Sciences, Lalitpur, Nepal, ${ }^{4}$ Department of Surgery, Patan Academy of Health Sciences, Lalitpur, Nepal, ${ }^{5}$ Department of Surgery, Patan Academy of Health Sciences, Lalitpur, Nepal.

\section{ABSTRACT}

Background: Patan Academy of Health Sciences (PAHS) aims to produce physicians who would be able and willing to serve in the rural areas. Recognizing the critical importance of student selection strategy, among others, in achieving the program goals, it has adopted an innovative scheme for selecting medical students. This paper describes PAHS medical student selection scheme that favors enrollment of deserving applicants from rural and disadvantaged groups so as to help improve distribution of physicians in rural Nepal.

Methods: A student admission committee comprising a group of medical educators finalized a three-step student selection scheme linked with scholarships after reviewing relevant literatures and consultative meetings with experts within and outside Nepal. The committee did local validation of Personal Quality Assessment (PQA) that tested cognitive ability and personality traits, Admission OSPE (Objective Structured Performance Examination) that assessed non-cognitive attributes of applicants. It also provided preferential credits to applicants' socio-economic characteristics to favor the enrollment of deserving applicants from rural and disadvantaged groups through Social Inclusion Matrix (SIM). Three different categories of scholarship schemes namely Partial, Collaborative and Full were devised with Partial providing 50\% and other two categories each providing 100\% coverage of tuition fee.

Results: PAHS student selection scheme succeeded in enrolling more than half of its students from rural areas of Nepal, including about $10 \%$ of the students from that of the most backward region of the country. About one third of students were female and about the same were from public and community school. Sixty percent of students receive different categories of scholarships.

Conclusions: Limited findings indicate the success of the selection scheme in enrolling high proportion of applicants from rural and disadvantageous groups and enable them to pursue study by providing scholarships.

Keywords: Admission OSPE; innovative student selection scheme; Nepal; Personal Quality Assessment; Social Inclusion Matrix.

\section{NTRODUCTION}

Apart from academic achievement, non-academic criteria have also been increasingly recognized as important desirable attributes among the applicants seeking a career in medicine and thus emphasized in selection of medical students. ${ }^{1-8}$ Likewise, widening access (WA) measures, that promote equity by addressing the disadvantages faced by applicants from rural and lower socio-economic background to enter medical career, is also being stressed in selection process. ${ }^{9-11}$ When coupled with the scholarship schemes, such selection process is likely to augment deployment and retention of graduates in rural areas. ${ }^{12-19}$

The Patan Academy of Health Sciences (PAHS) has adopted an innovative selection process that assesses, besides cognitive attributes, applicants' non-cognitive attributes as well as particular personality and attitudinal traits believed to be essential for the study and practice 
of medicine. ${ }^{1,2,5,20-21}$ Moreover, it allots preferential credits to applicants' socio-economic characteristics to positively favor the recruitment of students from rural and disadvantaged segments of Nepali society and provides them with scholarships.

This paper mainly aims to describe the innovative medical student selection scheme adopted by PAHS for its Bachelor of Medicine and Bachelor of Surgery (MBBS) program and its initial findings.

\section{METHODS}

A student admission committee formed under PAHS conducted a review of literatures in areas of student selection and consultations with academics within and outside $\mathrm{Nepal}^{22}$, and finalized a three-step selection scheme that is linked with scholarship provision.

First, the committee adapted the Personal Quality Assessment $(\mathrm{PQA})^{23}$ tool and validated it for local context in collaboration with the University of Newcastle (UoN) Australia, where it was developed. Administered as the written test, PQA comprised of the four subset of tests namely, Mental Agility Test (MAT); Moral Orientation in Justice and Caring (MOJAC); Narcissism, Aloofness, Confidence and Empathy (NACE) and Personal Characteristics Inventory $(\mathrm{PCl})$ to assess applicant's cognitive skills as well as particular personality and attitudinal traits. Applicants scoring below minus 2 Standard Deviation from the mean (-2SD) in the MAT (demonstrating low cognitive ability) and +/ 2SD in MOJAC, NACE and PCl (demonstrating extreme personality traits and values) were excluded from the selection process. Although the rest of the applicants were eligible for the second-step of selection process, only the eligible applicants from their MAT-score-based merit list were invited for further selection process. For the seats available under full payment category, applicants numbering four times the number of seats were invited for further selection. For the seats available under different categories of scholarship schemes, applicants numbering eight times the number of seats were invited for further selection.

The committee also constructed and validated the Admission OSPE (Objective Structured Performance Examination) stations, which is similar to Multiple Mini Interview (MMI) ${ }^{24}$ developed at McMaster University in Canada, with objective and structured scoring checklists to use as the second-step of the selection scheme. It was employed to assess applicants' various skills and qualities not assessable through written tests such as critical thinking; communication; decision making; organizational; and sensitivity, compassion and empathy. Faculty staffs, community members and professional actors were involved in the actual interview/observation process after undergoing rigorous trainings. ${ }^{25}$ Only those applicants who demonstrated satisfactory performance in Admission OSPE were placed in the further selection pool.

The third step of the selection scheme was the application of the matrix referred to as the 'Social Inclusion Matrix (SIM)' developed to address social accountability ${ }^{26}$ and inclusiveness in the spirit of PAHS Act ${ }^{27}$ as well as the then Interim Constitution of Nepal. The SIM included variables such as gender, caste/ethnicity, remoteness (rurality), community/public school background, applicants' rural health work experience and the Human Development Index (HDI) status of their place of permanent residence. Preferential credits were allotted to these variables based on applicants' socio-economic backgrounds. The total score obtained from PQA, Admission OSPE and SIM formed a final selection grid for scholarship seeking applicants. Only PQA and Admission OSPE scores were used for final selection of full paying category students.

Three different categories of scholarship schemes namely 'Partial', 'Full' and 'Collaborative' were devised so as to enable socially and economically disadvantaged applicants to study medicine if got selected. The Collaborative Scholarship Scheme, devised as a special cost sharing scheme, was introduced with the purpose of engaging the rural communities and local governments to contribute financially to cover the applicant's tuition fee, provided such applicants have passed the entire 3-step selection process. Provision was made such that an individual or organization can only sponsor a seat (not a particular applicant) for a given rural district, where $2 / 3^{\text {rd }}$ of student's tuition fee is covered by the sponsor/s and the remaining $1 / 3^{\text {rd }}$ covered by PAHS. Scholarship provision was worked out as such that nearly $60 \%$ of each student cohorts would receive one or other category of scholarships with Partial having $50 \%$ and Collaborative as well as Full each having $100 \%$ benefit in tuition fee coverage. All scholarship recipient students had to sign an agreement to serve in rural/remote areas for 2-4 years as assigned by Ministry of Health $(\mathrm{MoH})$, Nepal.

\section{RESULTS}

Admission data, based on the implementation of the selection scheme, for first three years of enrollment in MBBS program is presented in Table 1. Sixty students each were enrolled in year 2010 and 2011 and 55 students were enrolled in year 2012. Since the self paying category students were selected solely on the basis of 
PQA and Admission OSPE, and those under scholarship categories were selected based on the combination of all three steps, different characteristics of students have been shown in Table 1.
Table 1 shows that 34 out of 60 students each in year 2010 and 2011, and 31 out of 55 in 2012 received scholarship, which is around $60 \%$ of the total students.

Table 1. PAHS Social Inclusion Matrix, MBBS Program, 2010, 2011 \& 2012 Cohorts.

Cohort- 2010

\begin{tabular}{|c|c|c|c|c|c|c|c|c|c|}
\hline BLES & $\begin{array}{l}\text { Non } \\
\text { Scholar- } \\
\text { ship n } \\
\text { (\%) }\end{array}$ & $\begin{array}{l}\text { Scholar- } \\
\text { ship n } \\
\text { (\%) }\end{array}$ & All n (\%) & $\begin{array}{l}\text { Non } \\
\text { Scholar- } \\
\text { ship n } \\
(\%)\end{array}$ & $\begin{array}{l}\text { Scholar- } \\
\text { ship n } \\
\text { (\%) }\end{array}$ & $\begin{array}{l}\text { All } n \\
(\%)\end{array}$ & $\begin{array}{l}\text { Non } \\
\text { Scholar- } \\
\text { ship n } \\
(\%)\end{array}$ & $\begin{array}{l}\text { Scholar- } \\
\text { ship n } \\
\text { (\%) }\end{array}$ & All $n(\%)$ \\
\hline Gender (Female) & $\begin{array}{l}10 \\
(38.46 \%)\end{array}$ & $\begin{array}{l}8 \\
(23.52 \%)\end{array}$ & $\begin{array}{l}18 \\
(30.00 \%)\end{array}$ & $\begin{array}{l}14 \\
(53.84 \%)\end{array}$ & $\begin{array}{l}17 \\
(50.00 \%)\end{array}$ & $\begin{array}{l}31 \\
(51.67 \%)\end{array}$ & $\begin{array}{l}8 \\
(33.33 \%)\end{array}$ & $\begin{array}{l}5 \\
(16.13 \%)\end{array}$ & $\begin{array}{l}13 \\
(23.63 \%)\end{array}$ \\
\hline $\begin{array}{l}\text { Caste/Ethnicity - } \\
\text { Dalit }\end{array}$ & $\begin{array}{l}0 \\
(0.00 \%)\end{array}$ & $\begin{array}{l}0 \\
(0.00 \%)\end{array}$ & $\begin{array}{l}0 \\
(0.00 \%)\end{array}$ & $\begin{array}{l}0 \\
(0.00 \%)\end{array}$ & $\begin{array}{l}2 \\
(5.88 \%)\end{array}$ & $\begin{array}{l}2 \\
(3.33 \%)\end{array}$ & $\begin{array}{l}0 \\
(0.00 \%)\end{array}$ & $\begin{array}{l}2 \\
(6.45 \%)\end{array}$ & $\begin{array}{l}2 \\
(3.63 \%)\end{array}$ \\
\hline $\begin{array}{l}\text { Caste/Ethnicity - } \\
\text { Madhesi }\end{array}$ & $\begin{array}{l}1 \\
(3.84 \%)\end{array}$ & $\begin{array}{l}6 \\
(17.64 \%)\end{array}$ & $\begin{array}{l}7 \\
(11.66 \%)\end{array}$ & $\begin{array}{l}5 \\
(19.23 \%)\end{array}$ & $\begin{array}{l}9 \\
(26.47 \%)\end{array}$ & $\begin{array}{l}14 \\
(23.33 \%)\end{array}$ & $6(25 \%)$ & $\begin{array}{l}8 \\
(25.80 \%)\end{array}$ & $\begin{array}{l}14 \\
(25.45 \%)\end{array}$ \\
\hline $\begin{array}{l}\text { Caste/Ethnicity } \\
\text {-EM/IN }\end{array}$ & $\begin{array}{l}6 \\
(23.07 \%)\end{array}$ & $\begin{array}{l}10 \\
(29.41 \%)\end{array}$ & $\begin{array}{l}16 \\
(26.66 \%)\end{array}$ & $\begin{array}{l}5 \\
(19.23 \%)\end{array}$ & $\begin{array}{l}9 \\
(26.47 \%)\end{array}$ & $\begin{array}{l}14 \\
(23.33 \%)\end{array}$ & $\begin{array}{l}4 \\
(16.66 \%)\end{array}$ & $\begin{array}{l}5 \\
(16.13 \%)\end{array}$ & $\begin{array}{l}9 \\
(16.36 \%)\end{array}$ \\
\hline $\begin{array}{l}\text { Geographical } \\
\text { Region -Backward ( } 9 \\
\text { districts) }\end{array}$ & $\begin{array}{l}0 \\
(0.00 \%)\end{array}$ & $\begin{array}{l}2 \\
(5.88 \%)\end{array}$ & $\begin{array}{l}2 \\
(3.33 \%)\end{array}$ & $\begin{array}{l}0 \\
(0.00 \%)\end{array}$ & $\begin{array}{l}9 \\
(26.47 \%)\end{array}$ & $\begin{array}{l}9 \\
(15.00 \%)\end{array}$ & $\begin{array}{l}0 \\
(0.00 \%)\end{array}$ & $\begin{array}{l}6 \\
(19.35 \%)\end{array}$ & $\begin{array}{l}6 \\
(10.90 \%)\end{array}$ \\
\hline $\begin{array}{l}\text { Public/Community } \\
\text { School }\end{array}$ & $\begin{array}{l}0 \\
(0.00 \%)\end{array}$ & $\begin{array}{l}18 \\
(52.90 \%)\end{array}$ & $\begin{array}{l}18 \\
(30.00 \%)\end{array}$ & $\begin{array}{l}0 \\
(0.00 \%)\end{array}$ & $\begin{array}{l}15 \\
(44.10 \%)\end{array}$ & $\begin{array}{l}15 \\
(25.00 \%)\end{array}$ & $\begin{array}{l}0 \\
(0.00 \%)\end{array}$ & 24 (77\%) & $24(44 \%)$ \\
\hline $\begin{array}{l}\text { Rural Work } \\
\text { Experience }\end{array}$ & $\begin{array}{l}0 \\
(0.00 \%)\end{array}$ & $\begin{array}{l}0 \\
(0.00 \%)\end{array}$ & $\begin{array}{l}0 \\
(0.00 \%)\end{array}$ & $\begin{array}{l}0 \\
(0.00 \%)\end{array}$ & $\begin{array}{l}1 \\
(2.90 \%)\end{array}$ & $\begin{array}{l}1 \\
(1.67 \%)\end{array}$ & $\begin{array}{l}0 \\
(0.00 \%)\end{array}$ & $\begin{array}{l}0 \\
(0.00 \%)\end{array}$ & $\begin{array}{l}0 \\
(0.00 \%)\end{array}$ \\
\hline $\begin{array}{l}\text { Human Development } \\
\text { Index }\end{array}$ & $\begin{array}{l}0 \\
(0.00 \%)\end{array}$ & $\begin{array}{l}34 \\
(100 \%)\end{array}$ & $34(57 \%)$ & $\begin{array}{l}0 \\
(0.00 \%)\end{array}$ & $\begin{array}{l}34 \\
(100 \%)\end{array}$ & 34 (57\%) & $\begin{array}{l}0 \\
(0.00 \%)\end{array}$ & $\begin{array}{l}31 \\
(100 \%)\end{array}$ & $31(56 \%)$ \\
\hline Number of Students & 26 & 34 & 60 & 26 & 34 & 60 & 24 & 31 & 55 \\
\hline
\end{tabular}

Note: $E M / I N=$ Ethnic Minorities/Indigenous Nationalities

It also shows the percentage distribution of students selected by using the SIM criteria. The percentage of students in "dalit" category was 0 in 2010, 5.7\% (2 seats) in 2011 and $6.45 \%$ ( 2 seats) in 2012 . The selection process shows a more balanced selection of Madhesi and Ethnic Minorities/Indigenous nationalities in year 2011 and 2012 as compared to that of 2010.

A noticeable change can be observed in the selection of students from the backward areas which includes nine most remote districts of Mid-Western region of the country as defined by the government: $15 \%$ of the students were selected in 2011 and $10.9 \%$ in 2012 as compared to $3.33 \%$ in 2010 . The percentage of students graduating from government schools decreased from 52.9\% to $44.10 \%$ between 2010 and 2011 but increased again to $77 \%$ in 2012 among the scholarship recipients. There was one $(1.67 \%)$ student in 2011 who had at least two years experience in health institutions of remote area but there was no such student in 2010 and 2012. All the scholarship students got credits on Human
Development Index (HDI) based on the region of their permanent residence.

There was an increasing trend of scholarship students with permanent residence in rural areas, as defined by the government of Nepal, selected over 3 years $\mathbf{7 0 . 6 \%}$ in 2010, 76.5\% in 2011 and $80.6 \%$ in 2012) as shown in Table 2.

\begin{tabular}{|c|c|c|c|}
\hline \multirow[b]{2}{*}{$\begin{array}{l}\text { Place of } \\
\text { permanent } \\
\text { residence }\end{array}$} & \multicolumn{3}{|c|}{ Scholarship recipient students } \\
\hline & $\begin{array}{l}\text { Cohort- } \\
2010 \text { n(\%) }\end{array}$ & $\begin{array}{l}\text { Cohort- } \\
2011 \text { n(\%) }\end{array}$ & $\begin{array}{l}\text { Cohort- } \\
2012 \text { n(\%) }\end{array}$ \\
\hline Urban & $10(29.4 \%)$ & $8(23.5 \%)$ & $6(19.3 \%)$ \\
\hline Rural & $24(70.6 \%)$ & $26(76.5 \%)$ & $25(80.6 \%)$ \\
\hline Total & 34 & 34 & 31 \\
\hline
\end{tabular}


Similarly, the number of students selected with middle level health worker background was seven in 2012 and five each in year 2010 and 2011. Likewise, the students receiving scholarship under collaborative scheme almost doubled (7) in year 2012 as compared to that of four in year 2010 and three in year 2011 .

\section{DISCUSSION}

Effective deployment and sustained retention of healthcare professionals in underserved rural areas has remained a challenge both in developed and developing countries, ${ }^{12,28,29}$ including Nepal. In order to facilitate retention of physicians in the underserved rural areas and, thereby, improve the existing grossly skewed distribution of health human resources and service coverage for the population living in those areas, PAHS has adopted multi-pronged innovative approaches in medical education ${ }^{22,25,30,31}$ starting right from the student selection process.

PAHS enrolled a cohort of 60 students each in 2010 and 2011, and 55 students in 2012 as per the number of total seats approved by the Nepal Medical Council. Nearly 60\% of the selected students are provided with scholarship in different categories namely Partial, Collaborative and Full with Partial having $50 \%$ and Collaborative as well as Full each having $100 \%$ benefit in tuition fee coverage. Other medical schools in Nepal only provide $10-20 \%$ scholarship. ${ }^{32}$

Although the preliminary data shows that the student selection strategy employed by PAHS seems to have ensured a good representation of female, ethnic minorities/indigenous nationalities, only two students were selected from backward areas and none were selected from "Dalit" category in the first cohort of medical students. Thus, changes were made in admission directives to address this issue. Provisions were made to ensure selection of applicants from each of the disadvantaged categories (namely Female, Caste/Ethnicity-Dalit, Caste/Ethnicity-Madheshi, Ethnic minorities / Indigenous nationalities, Backward Areas) provided that they meet the minimum criteria in PQA and Admission OSPE. This resulted in the selection of two students from "Dalit" category each in the second and the third cohort (2011 and 2012), and increased selection of students from backward areas in both 2011 and 2012.

There has been a steady increment in the enrollment of students from rural origin in scholarship group (from 71 to $81 \%$ ) over three years, which is considered to be important in enhancing deployment of physicians in the rural/remote areas in future. ${ }^{12-19}$ Likewise, there has been marked increase in the number of students selected from public/community school in 2012 (77\%) as compared to that in 2010 (52.90\%) and 2011 (44.10\%), respectively among the scholarship students. Also, the enrollment of students under collaborative scholarship scheme has been almost doubled (7) in year 2012 as compared to that in 2010 (4) and 2011 (3). Increased awareness about the preferential selection process and collaborative scholarship scheme might have contributed to these increases.

\section{CONCUSIONS}

Recognizing the critical importance of appropriate student selection scheme in achieving the goals of its medical education program, PAHS has adopted a unique innovative scheme in selecting its medical students. Though limited, our initial findings indicate that this innovative scheme succeeded in enrolling high proportion of candidates from rural and disadvantageous groups.

\section{ACKNOWLEDGEMENTS}

We would like to acknowledge the technical assistant provided by Prof. David Powis, Miles Bore and Don Munro of the University of New Castle, Australia in the selection process of medical students.

\section{REFERENCES}

1. Greengross S. What patients want from their doctors. In: Hughes P. Can we improve on how we select medical students? J R Soc Med. 2002;95(1):18-22. [Link]

2. Kaiser F, Dewan HB, Mansoor F. Selection of Medical Students Admission and Selection Policy. RMJ. 2007;32(2):193-6. [Link]

3. Maharjan S, Dixit H. MBBS student selection: search for proper criteria. Kathmandu University Medical Journal. 2003;2(3):252-9. [Full Text]

4. Hughes P. Can we improve on how we select medical students? J R Soc Med. 2002;95(1):18-22. [Link]

5. Marley J, Carman I. Selecting medical students: a case report of the need for change. Medical Education. 1999;33(6):455-9. [Link]

6. Barr DA. Science as superstition: Selecting medical students. The Lancet. 2010;376:678-9. [Full Text]

7. Reede JY. Predictors of success in medicine. In: Hughes P. Can we improve on how we select medical students? J R 
Soc Med. 2002;95(1):18-22. [Link]

8. Salvatori P. Reliability and validity of admissions tools used to select students for the health professions. Adv Health Sci Educ. 2001;6(2):159-75. [Link]

9. Prideaux D, Roberts C, Eva K, Centeno A, Mccrorie $\mathrm{P}$, Mcmanus $\mathrm{C}$, et al. Assessment for selection for the health care professions and specialty training: Consensus statement and recommendations from the Ottawa 2010 Conference. Med Teach. 2011;33(3):215-23. [PubMed]

10. Powis D, Hamilton J, McManus IC. 2007. Widening access by changing the criteria for selecting medical students. Teaching and Teacher Education. 2007;23:1235-45. [Full Text]

11. Cleland J, Dowell J, McLachlan J, Nicholson S, Patterson F. Research report: Identifying best practice in the selection of medical students (literature review and interview survey). London: General Medical Council; 2012 Nov. [Full Text]

12. Wilson NW, Couper ID, De Vries E, Reid S, Fish T, Marais BJ. A critical review of interventions to redress the inequitable distribution of healthcare professionals to rural and remote areas. Rural Remote Health. 2009;9(2):1060. [PubMed]

13. Rourke, J. How can medical schools contribute to the education, recruitment and retention of rural physicians in their region? Bull World Health Organ. 2010;88:395-6. [PubMed]

14. Frenk J, Chen L, Bhutta ZA, Cohen J, Crisp N, Evans $\mathrm{T}$, et al. Health professionals for a new century: transforming education to strengthen health systems in an interdependent world. Lancet. 2010;376(9756):1923-58. [PubMed]

15. World Health Organization. Increasing access to health workers in remote and rural areas through improved retention: global policy recommendations. Geneva: World Health Organization; 2010 [cited March 2014]. [Link]

16. Laven G,Wilkinson D. Rural doctors and rural backgrounds: how strong is the evidence? A systematic review. Aust J Rural Health. 2003;11(6):277-84. [PubMed]

17. Playford D, Larson A, Wheatland B. Going country: rural student placement factors associated with future rural employment in nursing and allied health. Aust J Rural Health. 2006 Feb;14(1):14-9. [PubMed]

18. Easterbrook M, Godwin M, Wilson R, Hodgetts G,
Brown G, Pong R, et al. Rural background and clinical rural rotations during medical training: effect on practice location. CMAJ. 1999;160(8):1159-63. [PubMed]

19. Rolfe IE, Pearson SA, O'Connell DL, Dickinson JA. Finding solutions to the rural doctor shortage: the roles of selection versus undergraduate medical education at Newcastle. Aust N Z J Med. 1995;25(5):512-7. [PubMed]

20. Powis DA, Bore M, Munro D. Selecting medical students: Evidence based admissions procedures for medical students are being tested. BMJ. 2006;332(7550):1156.[PubMed]

21. Rizyal SB, Adhikari RK. Selection of students for medicine. In: Adhikari RK, Jayawickramarajah PT (edi). Essentials of medical education. Health Learning Materials Centre: Kathmandu, 1996.

22. Baral KP, Upadhyay SK, Bhandary S, Gongal RN, Karki A. Development of community based learning and education system within undergraduate medical curriculum of Patan Academy of Health Sciences. J Nepal Health Res Counc. 2016; 14:58-65. [PubMed]

23. Powis D, Bore M, Munro D, Lumsden MA. Development of the personal qualities assessment as a tool for selecting medical students. Journal of Adult and Continuing Education. 2005;11(1):3-14. [Link]

24. Eva KW, Reiter HI, Rosenfeld J, Norman GR. An admission OSCE: the multiple mini-interview. Med Educ. 2004;38:314-26. [PubMed]

25. Baral K, Allison J, Upadhyay S, Bhandary S, Shrestha S, Renouf T. Rural Community as Context and Teacher for Health Professions Education. Cureus. 2016;8(11):e866. [Link]

26. Boelen C. Adapting Health Care Institutions and Medical Schools to Societies' Needs. Acad Med. 1999;74(8):S1120. [PubMed]

27. Nepal Law Commission, Government of Nepal (GoN). Patan Academy of Health Sciences Act, 2064 (2008). Kathmandu: Nepal Law Comission; 2008 [Cited 2017 April 29]. [Full Text]

28. Dussault G, Franceschini MC. Not enough there, too many here: understanding geographical imbalances in the distribution of the health workforce. Hum Resour Health. 2006;4(1):12. [Link]

29. Lehmann U, Dieleman M, Martineau T. Staffing remote rural areas in middle-and low-income countries: a literature review of attraction and retention. BMC Fealth 
Admitting Deserving Medical Students from Rural and Disadvantaged: Patan Academy of Health Sciences' Approach

Serv Res. 2008;8(1):1. [PubMed]

30. Morgan JHC. Designing an assessment tool for professional attributes of medical graduates from a new medical school in Nepal. South East Asian Journal of Medical Education. 2009;3(1):3-7. [Link]

31. Courneya C, Dunne D. PAHS: a Nepali project with international implications. Clinical Governance: An International Journal. 2009;14(2):134-44. [Link]
32. Dixit H, Maharjan S. Review of Admission of MBBS Students at KMC. Kathmandu University Medical Journal. 2003;1(3):212-21. [Full Text] 